\title{
SINTESIS TURUNAN POLIEUGENOL SEBAGAI CARRIER BAGI RECOVERY LOGAM BERAT DENGAN TEKNIK MEMBRAN CAIR
}

\author{
M. Cholid Djunaidi ${ }^{1 *}$, Retno A. Lusiana ${ }^{1)}$, Pratama J. Wibawa ${ }^{1)}$, Dwi Siswanta ${ }^{2)}$ dan \\ Jumina $^{2)}$ \\ 1) Jurusan Kimia FMIPA UNDIP Semarang \\ Jl. Prof. Soedarto, SH, Tembalang, Semarang \\ ${ }^{2)}$ Jurusan Kimia FMIPA UGM \\ ${ }^{*}$ Penulis korespondensi: abi_fifa@yahoo.com
}

\begin{abstract}
Abstrak
Telah dilakukan sintesis senyawa asam poliuegenoksi asetat dan polieugenoksi asetil piridil karbinolat (suatu turunan polieugenoksi asetat dengan gugus aktif N) dari eugenol. Hasil sintesis digunakan sebagai ekstraktan logam berat dengan metode transport membran cair. Analisis struktur polimer yang terbentuk dilakukan dengan spektrometer infra merah, ${ }^{1} H$ NMR, KLT, dan uji kelarutan. Penentuan berat molekul relatif polimer menggunakan metode viscometer Ubbelohde. Transport logam dilakukan dengan Membran Cair Ruah (BLM) menggunakan sel gelas tipe $U$ terhadap campuran logam $\mathrm{Cu}$ (II), Fe (III), Ni (II), Cd (II), Zn (II), dan Cr (III) kesemuanya dalam bentuk garam klorida. Transport dilakukan pada fasa umpan dan penerima $\mathrm{HCl}$, konsentrasi logam masingmasing 50 ppm. Penentuan konsentrasi ion logam di fasa penerima sebelum dan sesudah transport dilakukan dengan spectrofotometer serapan atom, sedangkan perubahan $\mathrm{pH}$ yang menyertai diukur dengan pH meter. Hasil sintesis polieugenoksi asetat dan polieugenoksi asetil piridil karbinolat berupa serbuk amorf berwarna merah bata sampai coklat tua, dengan berat molekul 5.980 .854 $\mathrm{gram} / \mathrm{mol}$ dan $5.602 .282 \mathrm{gram} / \mathrm{mol}$. Hasil transport terhadap campuran logam menunjukkan polieugenoksi asetat dan polieugenoksi asetil piridil karbinolat dengan gugus $N$ hasil sintesis mampu mentransferkan campuran logam ke fasa penerima dengan urutan logam hard (Cr (III) dan Fe (III)) $>$ logam borderline (Ni (II), Zn (II) dan Cu (II)), logam soft Cd (II).
\end{abstract}

Kata kunci: membran cair, membran cair ruah, turunan polieugenol

\begin{abstract}
Synthesis of poliuegenoksi acetate and polieugenoksi acetil piridil karbinolat (a derivative of polieugenoksi acetate with active bunch N). Compounds result of synthesis was used as an extractant for heavy metal by liquid membrane method. Structure polymer formed analysis was done by spectrometer infra red, ${ }^{1} \mathrm{H} N M R, K L T$, and solubility test. Determination of molecule weight of relative polymer was determined the viscometer Ubbelohde method. Metal transport was done by BLM using U type glass cell, for mixture of Cu (II), Fe ( III), Ni (II), Cd (II), Zn (II), and Cr (III) in chloride salt. Transport was done at feed phase and $\mathrm{HCl}$ receiver phase, metal concentration of each is 50 ppm. Determination of metal ion concentration in receiver phase before and after transport was done by atomic absorption spectrophotometer, while the change of $\mathrm{pH}$ accompanying was measured by $\mathrm{pH}$ meter. Polieugenoksi acetate and polieugenoksi acetyl piridil karbinolat resulted were both in amorf, red brick colored until deep brown, molecule weight were 5,980,854 gram $/ \mathrm{mol}$, and 5,602,282 $\mathrm{gram} / \mathrm{mol}$. Result of transport to metal mixture showed polieugenoksi acetate and polieugenoksi acetyl piridil carbinolat with bunch $\mathrm{N}$ can transport metal mixture by order hard metal (Cr (III) and Fe (III)) $>$ borderline metal (Ni (II), Zn (II) and Cu (II)), soft metal Cd (II)
\end{abstract}

Keywords: liquid membrane, bulk liquid membrane, polieugenol derivatived

\section{PENDAHULUAN}

Senyawa pembawa (carrier) sangat menentukan efektifitas (\% ekstraksi tinggi) dan selektifitas tinggi pada berbagai teknik ekstraksi (ekstraksi pelarut), teknik membran cair baik membran ruah (BLM, Bulk Liquid Membrane)/tabung U, emulsi (ELM, Emulsion 
Liquid Membrane) maupun berpendukung (SLM, Supported Liquid Membrane) serta teknik lain yang memerlukan fase terikat contohnya adalah kromatografi fase terikat. Melihat fungsinya, maka mejadi menarik untuk mensintesis senyawa carrier yang memiliki sifat efektif dan selektif.

Indonesia dengan sumber daya alam yang melimpah, sangat kaya dengan senyawa bahan alam yang belum dimanfaatkan secara maksimal. Sebagai negara penghasil minyak atsiri utama di dunia, yang salah satunya adalah minyak daun cengkeh, Indonesia memenuhi hampir separuh dari kebutuhan minyak daun cengkeh dunia pada awal tahun delapan puluhan (Anwar, 1994). Kandungan eugenol dari minyak daun cengkeh sekitar 80-90\% berat (Guether, 1948). Eugenol dapat digunakan sebagai bahan awal sintesis suatu senyawa karena adanya tiga gugus fungsional yang terikat padanya, yaitu gugus alil, hidroksi dan metoksi. Melalui gugus alil, eugenol mampu dipolimerisasi menjadi polieugenol (Ngadiwiyana, 1996; Liestyowati, 1996; Ciszewski, 1999; Handayani, 1999; Rastuti, 1998). Sedangkan dari gugus hidroksi telah dapat disintesis gugus-gugus dengan keaktifan yang lebih besar, seperti karboksilat (Harwati, 2002; Lusiana, 2003; Handayani, 2004) ester (Lusiana, 2003).

Keberhasilan ekstraksi pelarut dan teknik pemisahan logam menggunakan membran cair ditentukan oleh kestabilan kompleks antara logam dan carrier (ekstraktan). Kestabilan kompleks ditentukan oleh faktor dominan yaitu jenis atom donor (gugus fungsi aktif) dari senyawa carrier (Peterson, 1996) yang sesuai dengan konfigurasi elektron logam.

Selain faktor gugus aktif yang mempengaruhi efektifitas dan selektifitas ekstraksi logam, Peterson juga menyebutkan faktor ukuran cincin (ring size) untuk makrosiklik atau panjang dan cabang gugus hidrofobik (Walkowiak, 1996; Fortunato, 2004).

Dengan melakukan polimerisasi eugenol dan pemasukan gugus aktif yang diharapkan selektif terhadap logam tertentu, maka dapat ditingkatkan pemanfaatan potensi eugenol yang melimpah di bumi Indonesia sebagai bahan jadi untuk senyawa carrier bagi keperluan recovery logam dengan teknik membran cair.

\section{METODE PENELITIAN}

Bahan kimia yang digunakan untuk pembuatan polimer maupun ion-ion logam untuk studi transport adalah bahan kimia berkualitas analitik (analytical grade) yang tersedia secara komersial.

Alat penelitian yang digunakan berupa Pipa U dan ekstraktor SLM. Alat untuk eksperimen transport merupakan hasil rekayasa sendiri di Laboratorium Kimia Analitik, FMIPA UNDIP. Peralatan analisis yang digunakan berupa viskometer Ubbelohde, spektrofotometer IR merk Shimadzu-8210PC, spektrofotometer ${ }^{\mathrm{l}} \mathrm{H}$ NMR merk JEOL-MY60, pH meter Metrohm,

\section{Prosedur Penelitian \\ Sintesis polieugeol}

Lima gram eugenol $(0,03 \mathrm{~mol})$ dimasukkan ke dalam labu leher tiga (250 mL) kemudian ditambahkan $\mathrm{BF}_{3}$ dietileter dimana penambahan dilakukan selama 2 jam sekali, masing-masing $0,5 \mathrm{~mL} \mathrm{BF}_{3}$ dietil eter. Setelah reaksi berlangsung selama 8 jam, polimerisasi dihentikan dengan penambahan $1 \mathrm{~mL}$ metanol. Endapan yang terbentuk dilarutkan dalam dietil eter, kemudian dicuci dengan akuades sampai netral. Setelah itu dikeringkan dengan menggunakan $\mathrm{Na}_{2} \mathrm{SO}_{4}$ anhidrat untuk menarik air. Pelarut (dietil eter) kemudian diuapkan.

Selanjutnya, polieugenol hasil sintesis ditimbang, ditentukan titik leburnya dan strukturnya dianalisis dengan IR, NMR, KLT, dan uji kelarutan, . $\mathrm{BM}$ ditentukan dengan metode viskometri Ubbelohde.

\section{Sintesis polieugeoksi asetat}

1. Tanpa Media

Sebanyak 1 gram polieugenol dimasukkan ke dalam labu didih ukuran $100 \mathrm{~mL}$, lalu ditambahkan larutan $\mathrm{NaOH}$ 33\% (33 g NaOH dalam $100 \mathrm{~mL}$ ) sebanyak 17,5 mL. Selanjutnya campuran diaduk dengan menggunakan pengaduk selama kurang lebih 30 menit, dan ditambahkan 12,5 mL larutan asam kloroasetat 50\% (50 gram dalam 100 ML air) sedikit demi sedikit dengan pipet tetes sambil terus diaduk. Setelah penambahan selesai, campuran dipanaskan pada penangas air mendidih selama kurang lebih 2 jam. Campuran didinginkan, kemudian ditambahkan $50 \mathrm{~mL}$ air dandiasamkan dengan $\mathrm{HCl} 6 \mathrm{M}$ sampai $\mathrm{pH}$ 1. Hasil ekstraksi berupa endapan didiamkan kemudian dilakuken penyaringan. Residu kemudian dicuci dengan air untuk menghilangkan kloroasetat yang tersisa dan dikeringkan dalam desikator. Selanjutnya dianalisis dengan IR, ${ }^{1} \mathrm{H}$ NMR.

2. Dengan Media Pelarut Eter

Prosedur yang digunakan sama dengan di atas akan tetapi polieugenol dilarutkan dengan pelarut eter terlebih dahulu sebelum dimasukan ke dalam labu didih.

\section{Sintesis polieugenoksi asetil piridil karbinolat}

Sebanyak 0,5 g asam polieugenoksi asetat dimasukkan ke dalam labu leher tiga ukuran $100 \mathrm{~mL}$ dengan peralatan tambahan (corong penambah, refluks). Asam polieugenoksi asetat tersebut ditambahkan tionil klorida secara tetes demi tetes dalam corong penambah selama kurang lebih 30 menit. Kemudian campuran direfluks selama 90 menit dalam penangas air hangat $\left(40^{\circ} \mathrm{C}\right)$, lalu dibiarkan dinginkan. Selanjutnya ke dalam campuran ditambahkan 0,01 mol piridil karbinol tetes demi tetes dalam corong penetes selama 30 menit dan direfluks kembali dalam penangas air hangat $\left(40^{\circ} \mathrm{C}\right)$ selama 60 menit. Setelah dingin hasil yang didapat dilarutkan dalam kloroform atau eter kemudian dicuci dengan air 
sampai pH mendekati netral. Hasil ekstraksi kemudian dihilangkan pelarut yang tersisa.

Selanjutnya hasil yang didapat dianalisis dengan spektrofotometri IR, ${ }^{1} \mathrm{H}-\mathrm{NMR}$, KLT, dan uji kelarutan serta titik leleh.

\section{Penentuan berat molekul polimer}

Penentuan berat polimer ini menggunakan metode viskositas dengan alat viscometer Ubbelohde. Dasar eksperimen ini adalah pengukuran waktu alir dari beberapa larutan polimer dengan konsentrasi berbeda. Dengan menggunakan waktu alir beberapa konsentrasi larutan polimer dan pelarut murni ditentukan viskositas relatif $\eta_{\text {rel }}$, viskositas spesifik $\eta_{\mathrm{sp}}$, viskositas tereduksi $\eta_{\text {red }}$ larutan polimer.

Persamaan yang digunakan adalah :

$$
\eta_{\mathrm{sp}} / \mathrm{C}=[\eta]+\mathrm{K}[\eta]^{2} \mathrm{C}
$$

Viskositas relatif :

Viskositas spesifik :

$$
\eta_{\text {rel }}=\mathrm{t} / \mathrm{t}_{0}
$$

Viskositas Tereduksi :

$$
\eta_{\mathrm{sp}}=\eta_{\mathrm{rel}}-1
$$

$$
\eta_{\text {red }}=\eta_{\text {sp }} / C
$$

Penentuan nilai viskositas intrinsik $(\eta)$ berdasarkan persamaan (Rosenthal, 1990)

Dibuat grafik viskositas tereduksi $\eta_{\text {sp }} / C$ lawan fungsi konsentrasi C. Dengan mengekstrapolasikan garis lurus $\eta_{\mathrm{sp}} / \mathrm{C}$ terhadap fungsi konsentrasi (C) ke C mendekati nol, akan didapat intersep yang merupakan nilai viskositas intrinsik polymer.

Berat molekul relatif rata-rata polimer ditentukan berdasarkan persamaan Mark-HouwinkSakurada (Rosenthal, 1990) :

dimana,

$$
[\eta]=\mathrm{K} \mathrm{M}^{\mathrm{a}}
$$

$\mathrm{K}=$ tetapan, $11.10^{-3}$

$\mathrm{M}=$ Massa Molekul Relatif

$\mathrm{C}=$ konsentrasi polimer $(\mathrm{gram} / \mathrm{ml})$

$\eta=$ viskositas larutan

$\eta_{\text {sp }}=$ viskositas spesifik

$\mathrm{a}=$ tetapan, 0,725

to = waktu alir pelarut (detik)

$\mathrm{t} \quad=$ waktu alir polimer (detik)

$\eta_{\mathrm{o}}=$ viskositas pelarut

Prosedur transport ion logam melalui membran cair dengan pembawa polieugenoksi asetat

Metode

: BLM 1

Fasa Umpan : $10 \mathrm{~mL} 50 \mathrm{ppm}$ campuran logam $\mathrm{Cu}, \mathrm{Cr}, \mathrm{Fe}, \mathrm{Ni}, \mathrm{Zn}, \mathrm{Cd}$ dalam garam klorida dalam $\mathrm{pH}$ 2,674

Fasa Organik/Membran : 30 mL 0,5 gram polieugenol asetat dalam kloroform

Fasa Penerima : $10 \mathrm{~mL} \mathrm{HCl} \mathrm{pH} \mathrm{0,674}$

Lama Pengadukan: 24 jam, dengan pengaduk di tengah
Prosedur transport ion logam melalui membran cair dengan pembawa polieugenoksi asetil piridil karbinolat

Metode

: BLM 1

Fasa Umpan : $10 \mathrm{~mL} 50 \mathrm{ppm}$ campuran logam $\mathrm{Cu}, \mathrm{Cr}, \mathrm{Fe}, \mathrm{Ni}, \mathrm{Zn}$, Cd dalam garam klorida dalam akuades $\mathrm{pH}$ 2,674 Fasa Organik. $16 \mathrm{~mL}$ Polieugenoksi Asetil Piridil Karbinolat diencerkan menjadi 30 mL dengan Pelarut kloroform

Fasa Penerima : $10 \mathrm{~mL} \mathrm{HCl} \mathrm{pH} \mathrm{0,647}$

Lama Pengadukan: 20 jam, dengan pengaduk di tengah

Metode : BLM 2

Fasa Umpan : $10 \mathrm{~mL} 50 \mathrm{ppm}$ campuran logam $\mathrm{Cu}, \mathrm{Cr}, \mathrm{Fe}, \mathrm{Ni}, \mathrm{Zn}$, Cd dalam garam klorida dalam aquades $\mathrm{pH}$ 2,561

Fasa Organik/Membran: 0,2 gram Polieugenoksi Asetil Piridil Karbinolat pelarut dietileter dilarutkan dalam $30 \mathrm{~mL}$ kloroform

Fasa Penerima : $10 \mathrm{~mL} \mathrm{HCl} \mathrm{pH} \mathrm{0,647}$

Lama Pengadukan: 4 jam, dengan pengaduk ditengah

\section{HASIL DAN PEMBAHASAN}

Sintesis Polieugenoksi Asetat

Mekanisme sintesis poliegenoksi asetat dapat dilihat pada Gambar 1 di bawah ini,

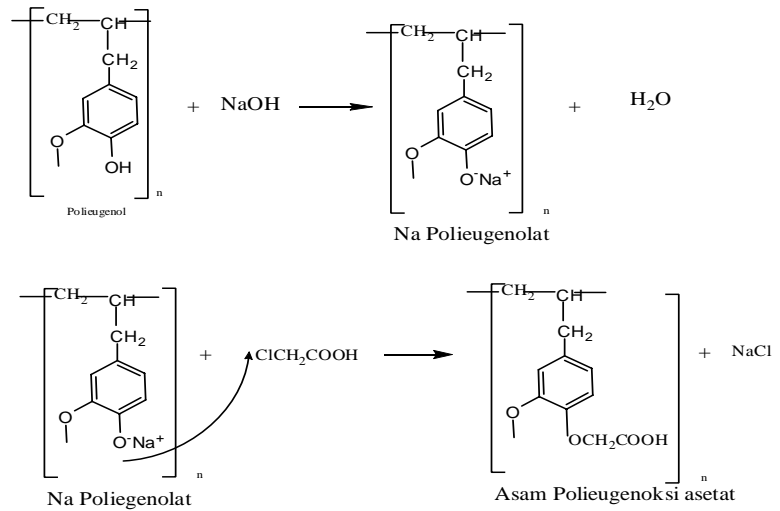

Gambar 1. Mekanisme reaksi sintesis asam polieugenoksi asetat

Selanjutnya hasil sintesis dikarakterisasi. Terdapat perbedaan hasil sintesis asam polieugenoksi asetat tanpa media dan dengan media pelarut eter. Sintesis dengan media, spektra gugus karbonil $(\mathrm{C}=\mathrm{O})$ asam pada daerah $1735 \mathrm{~cm}^{-1}$ tidak terlalu kuat (Gambar 2) sedangkan tanpa media cukup kuat (Gambar 3). Derajat/tingkatan gugus karboksilat yang dimiliki berpengaruh terhadap sifat kelarutan yang dimiliki oleh senyawa polieugenoksi asetat tersebut. Semakin banyak karboksilat yang dimiliki semakin bersifat polar sehingga larut dalam pelarut organik polar- 
semipolar. Sebaliknya dengan poliasetat tanpa media yang hanya larut dalam pelarut organik nonpolar. (Tabel 1)

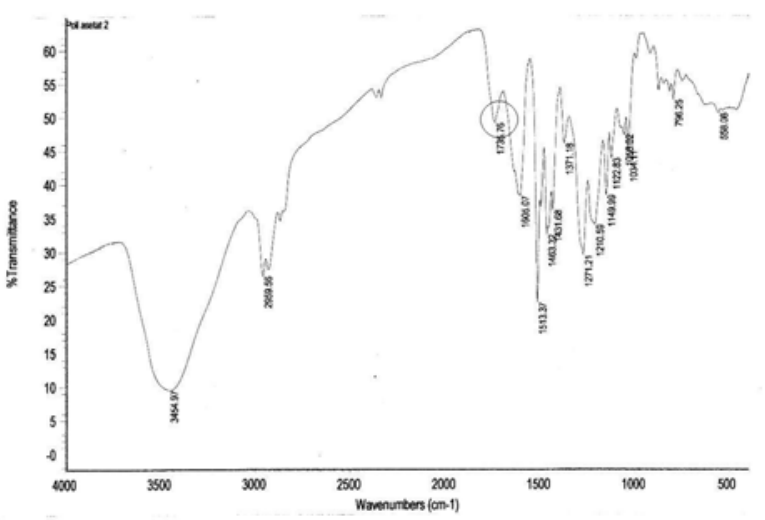

Gambar 2. Poliasetat dengan media eter

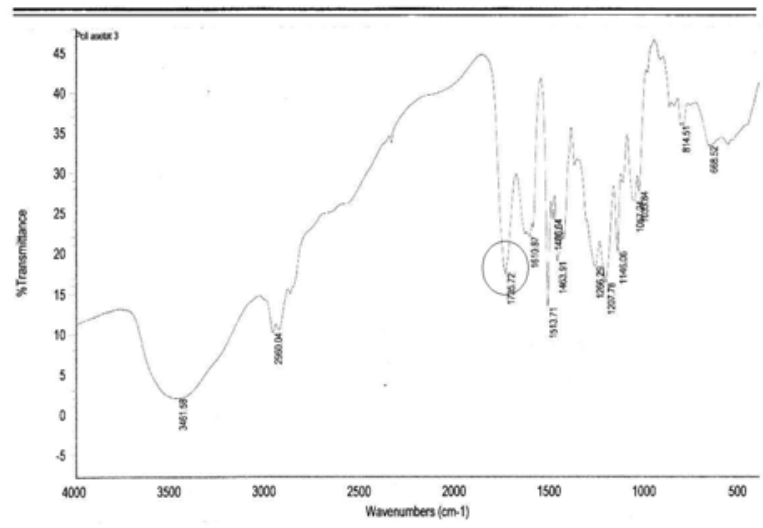

Gambar 3. Poliasetat tanpa media

Tabel 1. Sifat fisik dan kimia senyawa polieugeoksi asetat

\begin{tabular}{ll}
\hline Sifat Fisik & Sifat Kimia \\
\hline Wujud : padatan amorf & Dengan Media \\
Warna : merah - merah bata & Kelarutan : Larut dalam \\
Massa (g) : 1 gram (dengan & methanol, kloroform, dan \\
media), 1,38 gram (tanpa & tidak larut dalam karbon \\
media) & tetraklorida, heksana, dan \\
Titik Lebur : $105^{\circ} \mathrm{C}$ & kerosene (minyak tanah). \\
Berat Molekul relatif : & \\
5980,854 gram/mol & Tanpa Media \\
& $\begin{array}{l}\text { Kelarutan: Larut dalam } \\
\text { benzene, tak larut dalam } \\
\text { kloroform, methanol. }\end{array}$ \\
\end{tabular}

Jika diinterpretasikan diperoleh data seperti dalam Tabel 2 di bawah ini.
Tabel 2. Data interpretasi spectrum IR senyawa PEOA

\begin{tabular}{ll}
\hline \multicolumn{1}{c}{ Serapan $\mathrm{cm}^{-1}$} & \multicolumn{1}{c}{ Gugus karakteristik } \\
\hline 3454,9 & Hidroksil $(\mathrm{O}-\mathrm{H})$ \\
$3000-2800$ & Karbon jenuh $\left(\mathrm{C}_{\mathrm{sp}}{ }^{3}-\mathrm{H}\right)$ \\
1735 & Karbonil $(\mathrm{C}=\mathrm{O})$ \\
1605,5 dan 1513 & Aromatis $(\mathrm{C}=\mathrm{C})$ \\
1431 & Metilen $\left(-\mathrm{CH}_{2}-\right)$ \\
$1300-1000$ & Eter $(\mathrm{C}-\mathrm{O}-)$ \\
\hline
\end{tabular}

Sedangkan spektra ${ }^{1} \mathrm{H}$ NMR senyawa polieugenoksi asetat ditampilkan pada Gambar 4 dan Tabel 3 sebagai berikut:

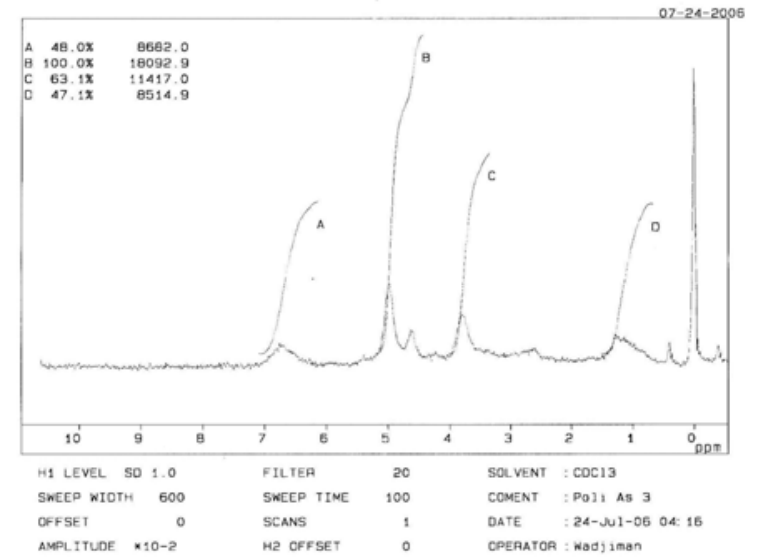

Gambar 4. Spektra ${ }^{1} \mathrm{H}$ NMR senyawa polieugenoksi asetat

Tabel 3. Korelasi antara sinyal 1H NMR dengan tipe proton PEOA

\begin{tabular}{lll}
\hline $\begin{array}{c}\text { Pergeseran } \\
\text { kimia } \delta(\mathrm{ppm})\end{array}$ & Hasil integrasi & Keterangan \\
\hline $6,7-7$ & $3 \mathrm{H}$ & $-\mathrm{C}_{6} \mathrm{H}_{3}, \mathrm{~s}$ \\
4,6 & $2 \mathrm{H}$ & $-\mathrm{OCH}_{2-}, \mathrm{s}$ \\
3,8 & $3 \mathrm{H}$ & $-\mathrm{OCH}_{3}, \mathrm{~s}$ \\
$0,5-1,5$ & $4 \mathrm{H}$ & $-\mathrm{CH}_{2}-\mathrm{CH}_{2^{-}}, \mathrm{m}$ \\
\hline
\end{tabular}

Spektra-spektra polieugenoksi asetat hasil isolasi di atas mirip dengan spektra polieugenoksi asetat hasil isolasi Harwati, dkk (2002) melalui jalur monomer.

\section{Transport membran cair}

Polieugenoksi asetat dengan media eter diujikan pada BLM dengan pelarut kloroform. Hasilnya dapat dilihat pada Gambar 5.

Dari Gambar 5 tampak bahwa transport menggunakan senyawa pembawa polieugenoksi asetat tidak berbeda besarnya antara logam hard (Cr (III) dan Fe (III)), soft (Cd (II)) dan borderline (Cu (II), Zn (II)). Hal ini terjadi karena sebagian gugus $\mathrm{OH}$ yang selektif terhadap logam hard telah tersubstitusi oleh gugus karboksilat yang cukup selektif terhadap gugus borderline dan soft (Harwati, 2002). Mekanisme transport adalah mekanisme pertukaran ion, dengan memanfaatkan ion $\mathrm{H}^{+}$yang dimiliki oleh gugus karboksil. Sehingga terjadi kenaikan $\mathrm{pH}$ di fasa umpan dan penurunan $\mathrm{pH}$ di fasa penerima. 


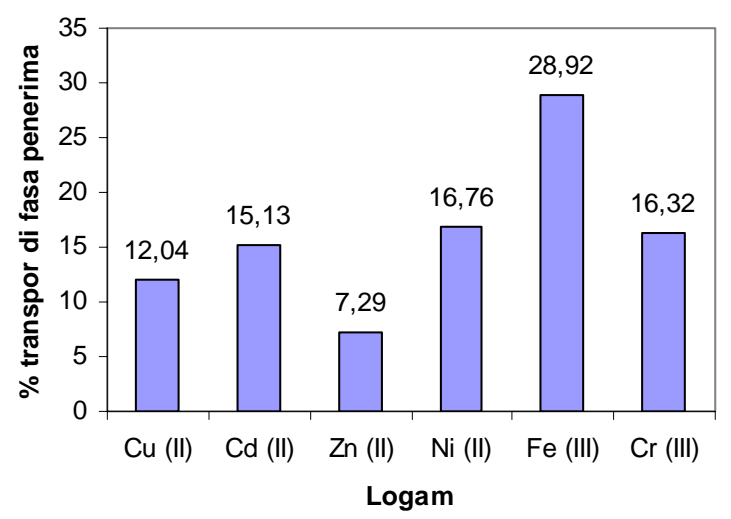

Gambar 5. Grafik \% transport logam di fasa penerima untuk senyawa pembawa polieugenoksi asetat

\section{Sintesis Polieugenoksi Asetil Piridil Karbinolat}

Sintesis poliugenoksi asetil piridil karbinolat dari polieugenoksi asetat diharapkan melalui tahapan reaksi seperti pada Gambar 6.

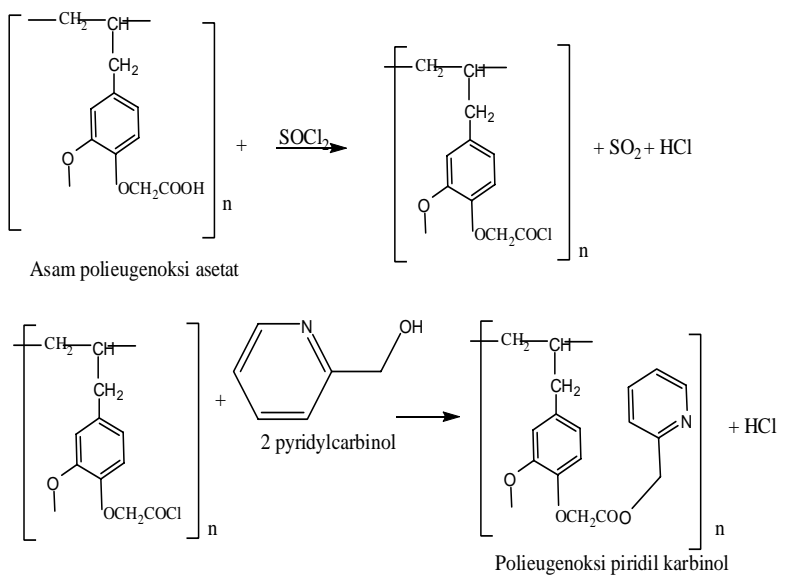

Gambar 6. Reaksi esterifikasi senyawa asam polieugenoksi asetat dengan piridil karbinol

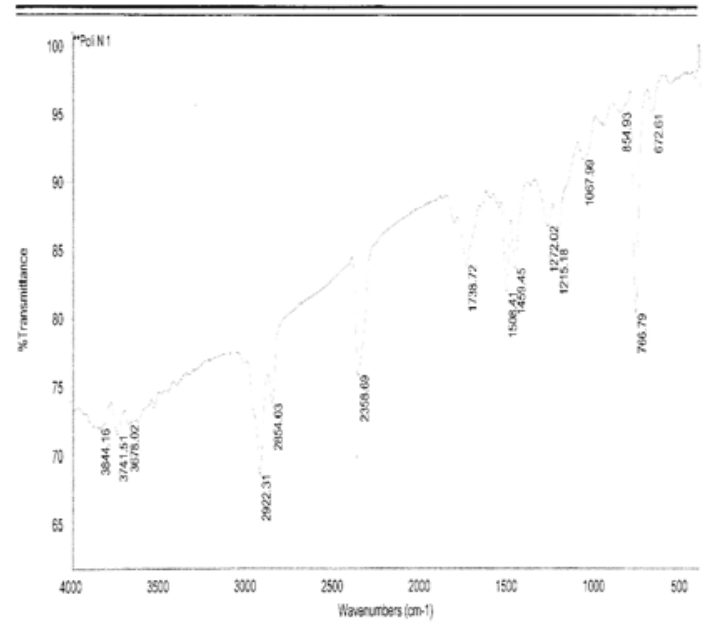

Gambar 7. Spektra IR senyawa polieugenoksi piridil karbinol dengan pelarut kloroform

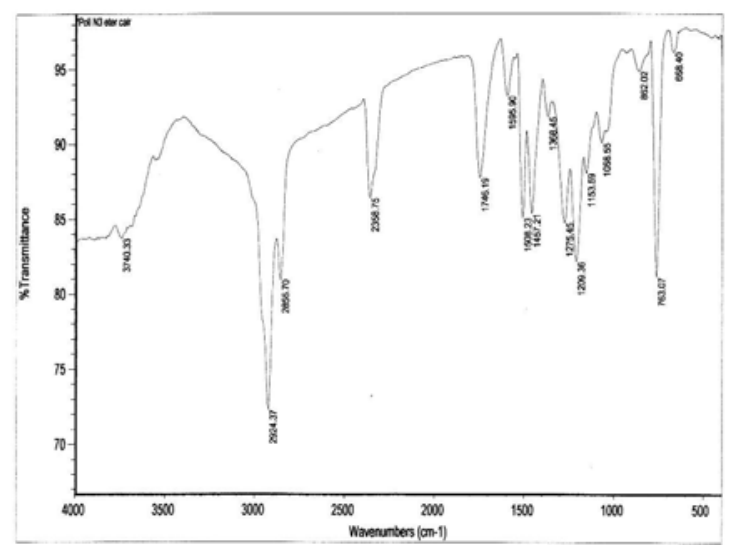

Gambar 8. Spektra IR senyawa polieugenoksipiridil karbinol dengan pelarut eter

Hasil IR senyawa polieugenoks asetil piridil karbinolat memperlihatkan gugus $\mathrm{OH}$ yang nampak kuat pada spectra polieugenoksi asetat di daerah 3400$3500 \mathrm{~cm}^{-1}$ menjadi hilang karena reaksi esterifikasi (Gambar 7 dan 8). Jika diinterpretasikan akan muncul data seperti dalam Tabel 4.

Tabel 4. Hasil analisis spectra inframerah turunan polieugenol

\begin{tabular}{|c|c|c|}
\hline \multirow[b]{2}{*}{$\begin{array}{c}\text { Gugus } \\
\text { Karakterisitik }\end{array}$} & \multicolumn{2}{|c|}{ Serapan $\left(\mathrm{cm}^{-1}\right)$} \\
\hline & $\begin{array}{c}\text { Asam } \\
\text { Polieugenoksi } \\
\text { Asetat } \\
\end{array}$ & $\begin{array}{l}\text { Polieugenoksi } \\
\text { Piridil Karbinol }\end{array}$ \\
\hline Gugus Hidroksil & Ada (3400-3500) & Tidak Ada \\
\hline $\begin{array}{l}\text { Gugus Karbon } \\
\text { jenuh }\end{array}$ & $\begin{array}{l}\text { Ada (2960 dan } \\
\text { 2841) }\end{array}$ & $\begin{array}{l}\text { Ada (2924 dan } \\
\text { 2854) }\end{array}$ \\
\hline $\begin{array}{l}\text { Gugus Karbonil } \\
\text { Ester }\end{array}$ & Tidak Ada & Ada (1745 cm-1) \\
\hline $\begin{array}{l}\text { Gugus Karbonil } \\
\text { Asam }\end{array}$ & Ada (1734 cm-1) & Tidak Ada \\
\hline Gugus aromatik & $\begin{array}{l}\text { Ada }(1608,25 \text { dan } \\
1513,37)\end{array}$ & $\begin{array}{l}\text { Ada (1595 dan } \\
\text { 1508) }\end{array}$ \\
\hline Gugus metilen & Ada $(1431,1)$ & Ada $(1431,1)$ \\
\hline Eter (C-O) & Ada (1300-1000) & Ada (1300-1000) \\
\hline $\begin{array}{l}\text { Aromatik } \\
\text { tersubstitusi }\end{array}$ & Ada $(814,51)$ & Ada $(862,02)$ \\
\hline
\end{tabular}

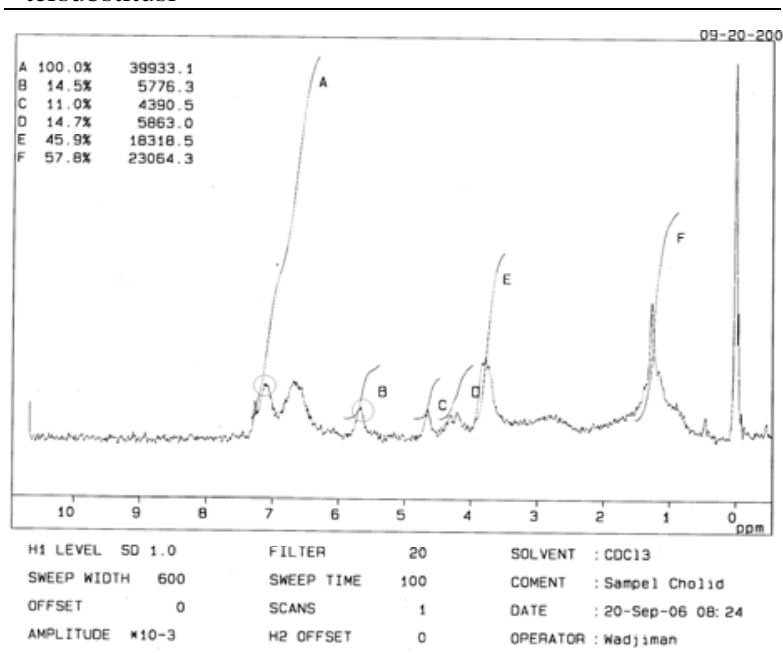

Gambar 9. Spektra ${ }^{1} \mathrm{H}$ NMR senyawa polieugenoksi piridil karbinol dengan pelarut eter 


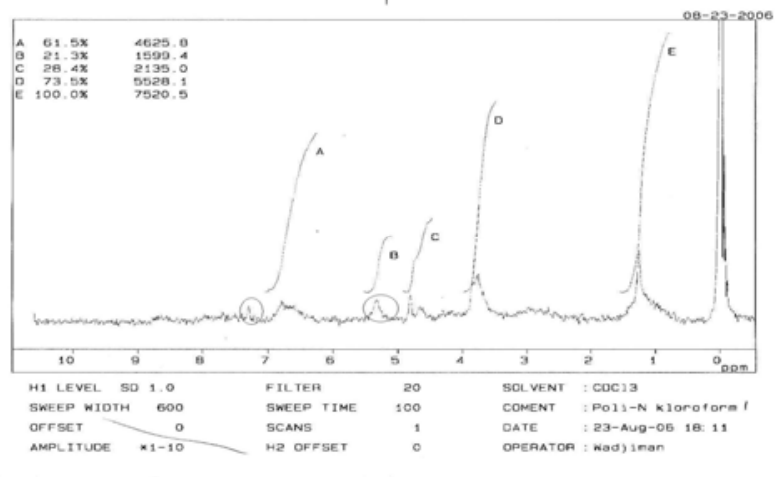

Gambar 10. Spektra ${ }^{1} \mathrm{H}$ NMR polieugenoksi piridil karbinol dengan pelarut kloroform

Hasil spectra ${ }^{1} \mathrm{H}$ NMR senyawa polieugenoksi piridil karbinol dapat dilihat pada Gambar 9 dan 10 . Jika diinterpretasikan maka akan diperoleh data seperti pada Tabel 5 berikut ini.

Tabel 5. Spektra ${ }^{1} \mathrm{H}$ NMR senyawa polieugenoksi piridil karbinolat

\begin{tabular}{lll}
\hline $\begin{array}{c}\text { Pergeseran } \\
\text { kimia } \delta(\mathrm{ppm})\end{array}$ & Hasil integrasi & \multicolumn{1}{c}{ Keterangan } \\
\hline 7,3 & $1 \mathrm{H}$ & $-\mathrm{CH}$ piridin,s \\
$6,7-7$ & $3 \mathrm{H}$ & $-\mathrm{C}_{6} \mathrm{H}_{3}, \mathrm{~s}$ \\
5,6 & $2 \mathrm{H}$ & $-\mathrm{CH}_{2}, \mathrm{~s}$, \\
& & $\begin{array}{l}\text { metilen piridil } \\
\text { karbinol }\end{array}$ \\
4,6 & & $-\mathrm{OCH}_{2-}, \mathrm{s}$ \\
3,8 & $2 \mathrm{H}$ & $-\mathrm{OCH}_{3}, \mathrm{~s}$ \\
$0,5-1,5$ & $3 \mathrm{H}$ & $-\mathrm{CH}_{2}-\mathrm{CH}_{2^{-}}, \mathrm{m}$ \\
\hline
\end{tabular}

Dari data spektra ${ }^{1} \mathrm{H}$ NMR dan IR di atas disimpulkan bahwa telah terbentuk ester polieugenoksi piridil karbinolat. Sebagai perbandingan di bawah ini adalah spectra NMR dari 2 piridil karbinol (Gambar 11).

Hal ini didukung oleh penentuan titik leleh, berat molekul, dan kelarutan senyawa-senyawa turunan polieugenol (Tabel 6).

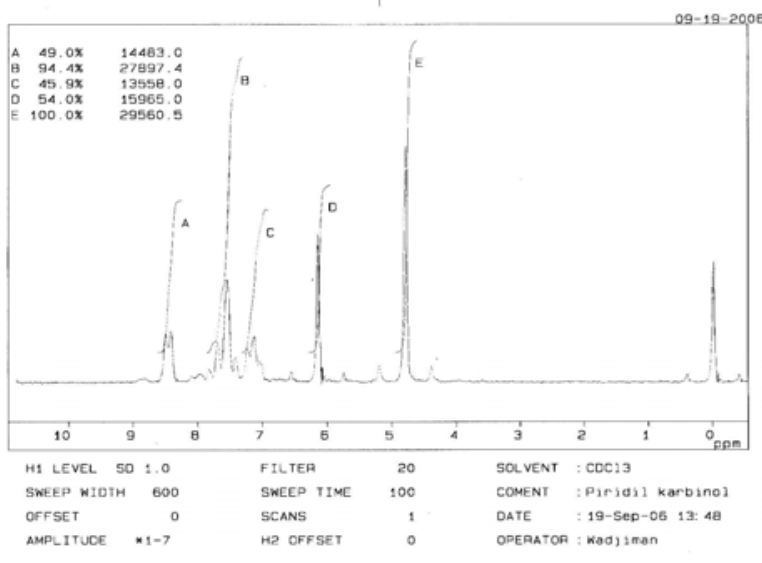

Gambar 11. Spektra ${ }^{1}$ H NMR piridil karbinol

\section{Transpor membran cair}

Senyawa hasil sintesis diujikan daya ekstraksinya menggunakan teknik membran cair ruah (BLM) dengan pelarut kloroform.

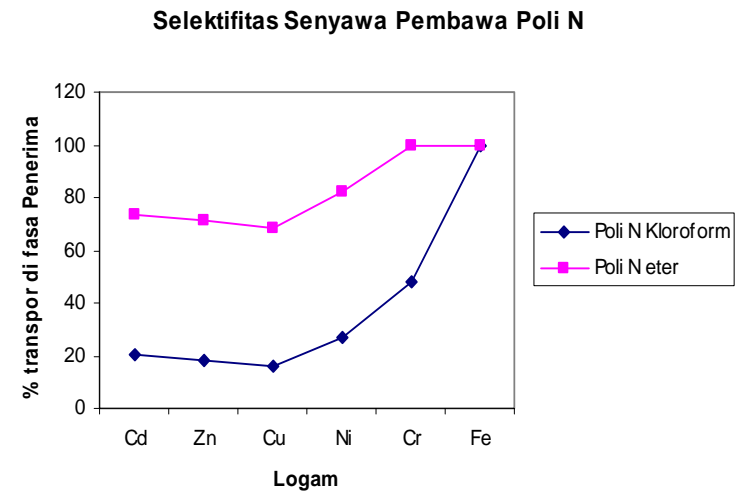

Gambar 12. Selektifitas senyawa pembawa poli N terhadap logam

Pada Gambar 12 terdapat perbedaan \% transport logam yang sampai di fasa penerima. Hal ini karena konsentrasi senyawa pembawa yang berbeda, dimana konsentrasi senyawa pembawa poli $\mathrm{N}$ eter lebih pekat daripada poli N kloroform.

Tabel 6. Sifat fisika dan kimia senyawa turunan polieugenol

\begin{tabular}{|c|c|c|c|}
\hline Senyawa & Titik Leleh & Kelarutan & $\mathrm{Rf}$ \\
\hline $\begin{array}{l}\text { Polieugenoksi asetat } \\
\text { BM: } 5980.854\end{array}$ & $105^{\circ} \mathrm{C}$ & $\begin{array}{l}\text { Tak larut dalam kloroform, } \\
\text { larut dalam methanol }\end{array}$ & Pelarut Metanol 0,7 \\
\hline Bau: Tidak Berbau & & & Pelarut kloroform 0,88 \\
\hline $\begin{array}{l}\text { Poli eugenoksi piridil karbinolat } \\
\text { dalam pelarut kloroform } \\
\text { Bau: Harum }\end{array}$ & $96^{\circ} \mathrm{C}$ & $\begin{array}{l}\text { Larut kloroform, methanol, } \\
\text { benzena }\end{array}$ & Pelarut Metanol: 0,8 \\
\hline $\begin{array}{l}\text { Poli eugenoksi piridil karbinolat } \\
\text { dalam pelarut eter } \\
\text { BM 5602.282 } \\
\text { Bau: Harum }\end{array}$ & $90^{\circ} \mathrm{C}$ & $\begin{array}{l}\text { Larut kloroform, methanol, } \\
\text { benzena }\end{array}$ & $\begin{array}{l}\text { Pelarut Metanol : 0,8 } \\
\text { Pelarut Kloroform: } \\
0,92\end{array}$ \\
\hline
\end{tabular}


Dari Gambar 12 tampak pula bahwa logam hard masih memiliki selektifitas yang paling tinggi Walaupun jika dibandingkan dengan senyawa turunan yang lain logam-logam border line dan soft meningkat cukup signifikan persen transport-nya di fasa penerima.

Jika dibandingkan \% transport di fasa penerima antara turunan-turunan polieugenol diperoleh grafik seperti Gambar 13.

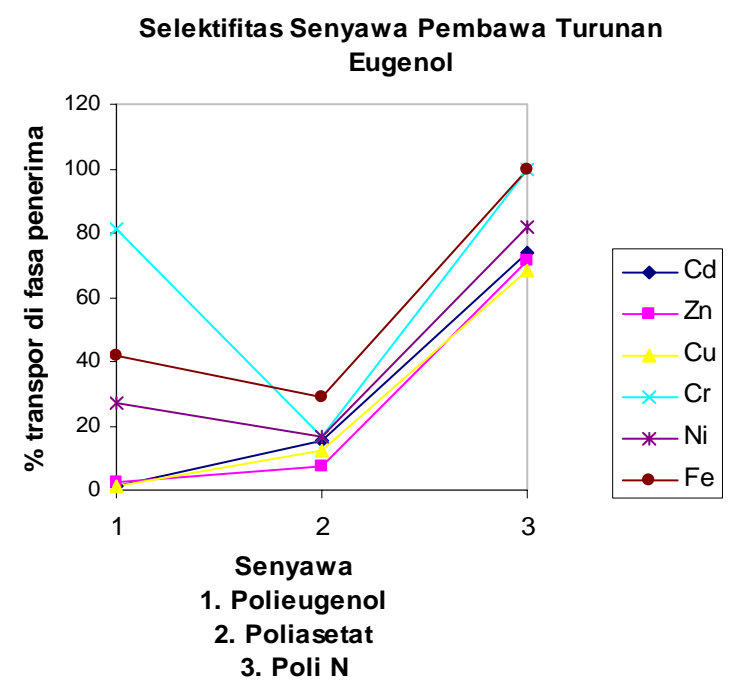

Gambar 13. Grafik selektifitas senyawa pembawa turunan eugenol terhadap logam

Dari Gambar 13 terlihat bahwa dibandingkan dengan turunan eugenol lainnya, poli $\mathrm{N}$ cukup superior dalam mentransport logam-logam baik logam hard, borderline maupun soft. Walaupun konsentrasi dan waktu pengadukan yang lebih kecil/pendek daripada turunan eugenol lainnya. Hal ini kemungkinan diakibatkan oleh banyaknya gugus penyedia elektron bebas ( $\mathrm{N}$ dan $\mathrm{O}$ ) yang dimilikinya. Kekayaan ini menyebabkan senyawa hasil sintesa kurang selektif terhadap salah satu kelompok logam.

Terjadi perubahan $\mathrm{pH}$ setelah pengadukan 24 jam menggunakan teknik membran cair ruah (BLM) selama 24 jam dengan senyawa pembawa poliasetat (polieugenoksi asetat) dan poli $\mathrm{N}$ (polieugenoksi pirdil karbinoat) seperti nampak pada Tabel 7.

Tabel 7. Perubahan $\mathrm{pH}$ sebelum dan sesudah pengadukan pada berbagai teknik membran cair

\begin{tabular}{lcccc}
\hline \multirow{2}{*}{$\begin{array}{c}\text { Jenis Membran } \\
\text { Cair }\end{array}$} & \multicolumn{2}{c}{$\mathrm{pH}$ umpan } & \multicolumn{2}{c}{$\mathrm{pH}$ penerima } \\
\cline { 2 - 5 } & $\begin{array}{c}\text { Mula- } \\
\text { mula }\end{array}$ & $\mathrm{pH} \mathrm{t}$ & $\begin{array}{c}\text { Mula- } \\
\text { mula }\end{array}$ & $\mathrm{pH} \mathrm{t}$ \\
\hline BLM Poliasetat 1 & 2,674 & 1,163 & 0,647 & 1,107 \\
BLM Poliasetat 2 & 2,674 & 1,670 & 0,647 & 0,992 \\
BLM Poli N & 2,674 & 1,120 & 0,647 & 1,154 \\
kloroform & & & & \\
BLM Poli N eter & 2,674 & 1,408 & 0,647 & 1,067 \\
\hline
\end{tabular}

Dari Tabel 7 dapat disimpulkan bahwa senyawa poli $\mathrm{N}$ mentranspor logam dari fasa umpan menuju fasa penerima menggunakan kelebihan elektron atom $\mathrm{N}$ dan atom $\mathrm{O}$ yang dimilikinya, setelah itu logam dipertukarkan dengan ion $\mathrm{H}^{+}$di fasa penerima. Senyawa pembawa poli $\mathrm{N}$ yang membawa ion $\mathrm{H}^{+}$dari fasa penerima selanjutnya menukarkan ion $\mathrm{H}^{+}$dengan logam di fasa umpan. Sehingga diperoleh penurunan $\mathrm{pH}$ di fasa umpan dan kenaikan $\mathrm{pH}$ di fasa penerima.

\section{KESIMPULAN}

Senyawa pembawa polieugenoksi asetat lebih menyukai logam borderline. Adanya gugus $\mathrm{N}$ mampu meningkatkan \% transport logam borderline dan soft di fasa penerima. Poli $\mathrm{N}$ kurang selektif karena banyaknya gugus penyedia elektron bebas ( $\mathrm{N}$ dan $\mathrm{O}$ )

\section{SARAN}

Perlu dipelajari kemungkinan sintesis polieugenoksi asetat dan poli $\mathrm{N}$ dengan mensintesis monomer lebih dahulu, sehingga dapat dibandingkan tingkat berhasilannya dan karakterisasi yang dilakukan lebih valid.

\section{DAFTAR PUSTAKA}

Anwar, C., (1994), The Conversion of Eugenolin to more Valuable substances, Disertasi, Faculty of mathematics and Natural Sciences in Gadjah Mada University, Yogyakarta.

Ciszewski, A., et al, (1999), Polyeugenol-Modified Platinum Electrode for Selective Detection of dopamine in The Presence of Ascorbic Acid, Anal. Chem., 71, 1055-1061.

Fortunato, R., et al, (2004), Supported Liquid Membrane Using Ionic Liquids: Study of Stability and Transport Mechanism, J. Membrane Science, 242, p, 197-209

Guenther, E., (1948), The Essential Oils, Individual essential Oils of the Plant Familities, Vol 4, D, Van Nostrand. Co, Inc., New York, 436-437.

Handayani, S., (1999), Sintesis Poli (eugenil Sulfonat) dan Aplikasinya Sebagai Katalis Asam dalam Siklisasi Sitronelal, Thesis, Universitas Gadjah Mada, Jogjakarta

Handayani, W., (2001), Sintesis polieugenol dengan katalis asam sulfat. Jurnal Ilmu Kimia Dasar, FMIPA Universitas Jember, Volume 2 Nomer 2, hal 103-110.

Harwati, Umi, T., Siswanta, D., dan Hadipranoto, N., (2004), Ligan Baru yang Selektif Terhadap Cu(II) dalam Transport Membran Cair, Sains dan Sibernatika, Berkala Penelitian Pasca Sarjana Ilmuilmu Sains, Universitas Gadjah Mada, Vol. 17 (4) hal 537-545.

Liestyowati, (1996), Polimerisasi Eugenol Dengan Katalis $\mathrm{BF}_{3}$, Skripsi, Universitas Gadjah Mada, Jogjakarta. 
Lusiana, R.A, (2003), Sintesis Oktileugeniloksi Etanoat Dari Eugenol, Jurnal Kimia Sains dan Aplikasi, Vol. VI, No. 1, 2003, p. 6-10.

Natpro, Topik, no. 1 vol 3 Januari (1993)

Ngadiwiyana, (1996), Polimerisasi Eugenol Dengan Katalis Asam Sulfat Pekat, Skripsi, Universitas Gadjah Mada, Jogjakarta

Peterson, R.T, (1996), Design of Macrocyclic Carriers for Liquid Membrane, In Chemical Separations with
Liquid Membranes, American Chemical Society, Washington DC.

Rastuti, U., (1998), Pengaruh Media pada Polimerisasi Eugenol dengan Katalis Asam Sulfat Pekat dan Sintesis Polielektrolit, Skripsi, Universitas Gadjah Mada, Jogjakarta.

Walkowiak, W. and J. Gega, (1996), Transition Metal Cation Separation by Organophosphorus Compounds in Liquid Membrane Processes, C.S. Symposium Series 642. Chemical Separations with Liquid Membrane-, American Chemical Society, pp.181-193. 